\title{
FORMULASI SUSPENSI KERING KOMBINASI EKSTRAK ETANOL KUNYIT (Curcuma longa L.) DAN SERBUK DAGING BUAH PISANG KEPOK (Musa balbisiana Colla.) DENGAN VARIASI BAHAN PENSUSPENSI
}

\author{
Nurlina*), M. Ilham Tomagola"), Nursiah Hasyim ${ }^{* *}$, Fadjaruddin Rahman ${ }^{*}$ \\ ${ }^{*}$ Fakultas Farmasi Universitas Muslim Indonesia \\ ${ }^{* *}$ Fakultas Farmasi Universitas Hasanuddin \\ Email : lina.adin@gmail.com
}

\begin{abstract}
Background :For long time ago various research has been done on both curcuma and banana fruit. Result showed that curcumin which contained in curcuma and cytoindosin, tannin, amylum on banana function as antipeptic ulcer. PUD (peptic ulcer disease) is remain the most common disease of gastrointestinal tract, so which influence life quality, disorder in works, and higher of medical treatment cost. Most of patient of which expect prompt effect of preparations. Based on this, suspension was made to give the prompt effect, due to fine particles of the suspensoid which is not degradated or aggregated in time.

The Aim :to obtain dry suspension from which is pharmaceutically stable from combination of curcuma (Curcuma longa L.) aethanolic extracts and the powder of banana (Musa balbisiana Colla.) flesh using a various of suspending agent.

Method : it was experimental method which was a research method in laboratory conducted by preparing some formulation designs of dry suspension fromcombination of curcuma (Curcuma longa L.) aethanolic extracts and the powder of banana (Musa balbisiana Colla.) flesh.

Conclusion :the suspending agent producing the pharmaceutically stable dry suspension is magnesium aluminium silicate with $4 \%$ concentration
\end{abstract}

Keyword : Curcuma, Banana Fruit, Dry Suspension, Peptic Ulcer.

\section{PENDAHULUAN}

Sifat-sifat kunyit yang dapat menyembuhkan luka sudah dilaporkan sejak tahun 1953. Penelitian terhadap ekstrak kunyit dalam melindungi tukak lambung dan memperoleh hasil bahwa ekstrak kunyit dapat menghambat tukak lambung dengan memblok reseptor histamin $\mathrm{H}_{2}$. (Kim., dkk, 2005).
Selain kunyit, pisang (Musa balbisiana Colla.) dari keluarga Musaceae pun secara empiris digunakan sebagai obat sakit lambung. Pengobatan tradisional India Ayurveda menggunakan bubuk pisang untuk mengobati penderita maag disertai tukak. Dari penelitian yang dilakukan tim gabungan Inggris dan India terhadap hewan percobaan, yaitu tikus 
Formulasi Suspensi Kering Kombinasi Ekstrak Etanol Dan Serbuk Daging Buah Pisang Kepok Dengan Variasi Bahan Pensuspensi

yang diinduksi aspirin, terbukti bubuk pisang mentah dapat melindungi lambung dari tukak. Selain itu ada beberapa laporan yang menghubungkan pisang dengan sifat anti-ulcerogenic dimana pisang merangsang proliferasi sel dan lendir yang membentuk penghalang kuat antara lambung dan asam.. Berdasarkan uji pendahuluan antiulkus dari pisang yang dilakukan oleh Vadivelan, R., dkk (2006) terhadap tikus putih diperoleh bahwa dosis pisang yang dapat mengobati ulkus adalah $20 \mathrm{mg} / \mathrm{kgBB}$.

PUD (Peptic Ulcer Disease) tetap menjadi salah satu penyakit yang paling umum pada Gastointestinal, sehingga memberikan pengaruh dalam gangguan kualitas hidup, kerugian dalam bekerja, dan biaya perawatan medis yang tinggi. Insiden bervariasi dengan ulkus pada usia, jenis kelamin, ras, pekerjaan, predisposisi genetik, lokasi geografis, dan faktor sosial yang mungkin memainkan peran kecil dalam patogenesis ulkus, tetapi dilemahkan oleh pentingnya infeksi $H$. pylori dan penggunaan obat anti-inflamasi nonsteroid (NSAID) (Dipiro, 2008).

Kebanyakan pasien yang terkena ulkus menginginkan suatu sediaan dengan efek yang cepat. Berdasarkan hal ini maka sediaan yang dapat menghasilkan efek yang cepat adalah suspensi. Karena ukuran partikel dari zat tersuspensi sangat kecil sehingga tidak membutuhkan waktu untuk terdegradasi maupun teragreagsi. Namun, karena kandungan amilum dari pisang yang baik untuk pertumbuhan mikroorganisme ketika terhidrasi maka salah satu cara untuk menghindari hal tersebut salah satunya adalah dibuat dalam bentuk suspensi kering.

\section{METODE PENELITIAN}

\section{Alat dan Bahan}

Alat yang digunakan dalam penelitian ini adalah Refrigerator, Mikroskop optic, pH Meter, Viskometer Brookfield, Tab Densitor, dan alat-alat gelas yang digunakan dalam analisis.

Sedangkan Bahan-bahan yang digunakan dalam penelitian ini adalah Air Suling, Etanol 80\%, Rimpang Kunyit (Curcuma longa L.), Daging Buah Pisang Kepok (Musa balbisiana Colla), Gum Xanthan, Magnesium Aluminium Silikat, Metil Paraben, Natrium Karboksimetilselulosa, Sukrosa,

\section{Prosedur Kerja}

\section{Penyiapan Sampel Uji}

Sampel yang digunakan adalah rimpang kunyit (Curcuma longa L.) dan daging buah pisang kepok (Musa 
Formulasi Suspensi Kering Kombinasi Ekstrak Etanol Dan Serbuk Daging Buah Pisang Kepok Dengan Variasi Bahan Pensuspensi

balbisiana Colla) asal kota Makassar

Propinsi Sulawesi Selatan. Rimpang kunyit yang telah dibersihkan dan dikeringkan, kemudian dimaserasi dan diuapkan sampai kering untuk memperoleh ekstrak keringnya. Sedangkan daging buah pisang kepok diiris-iris tipis kemudian dikeringkan dan diserbukan untuk memperoleh serbuk buah pisang kepok.

Penyiapan Suspensi Kering

Dilakukan optimasi terhadap bahan pensuspensi dengan tujuan untuk memperoleh konsentrasi yang dapat menghasilkan suspensi kering dengan kekentalan yang optimum.

\section{Pengujian Secara Farmaseutik}

Evaluasi kestabilan suspensi dilakukan dalam dua tahap, yaitu evaluasi kestabilan untuk suspensi kering dengan parameter Uji Kadar Air (Lost on Drying), Sudut Baring (Angle of Repose), BJ Mampat, BJ Sejati (True Density) dan Porositas. Serta evaluasi kestabilan untuk suspensi basah, yang dilakukan dengan metode Freeze-thaw yaitu penyimpanan dipercepat pada kondisi dipaksakan dilakukan dengan cara menyimpan suspensi yang sebelumnya telah direkonstitusi dengan air pada dua suhu ekstrim, yaitu pada suhu $5^{\circ} \mathrm{C}$ yang dimasukan dalam lemari pendingin dan $35^{\circ} \mathrm{C}$ dalam lemari pemanas secara bergantian masingmasing 12 jam selama 10 kali siklus dengan parameter uji organoleptis, uji homogenitas, viskositas dan tipe aliran, nilai $\mathrm{pH}$ dan pengamatan partikel tersuspensi.

\section{Pemeriksaan Organoleptis}

Data-data yang dikumpulkan pada pemeriksaan organoleptis meliputi warna, bau dan konsistensi dari sediaan suspensi kering setelah direkonstitusi.

\section{Pengujian Kadar Air}

Data kadar air diperoleh dengan cara berat sampel sebelum dikeringkan dikurangi dengan berat sampel setelah dikeringkan, kemudian dibagi dengan berat sampel sebelum dikeringkan dan dikali dengan seratus persen. Data yang diperoleh digunakan sebagai parameter kandungan air yang ada dalam suspensi kering.

\section{Penentuan Sudut Baring dan Waktu} Alir

Serbuk dimasukkan dalam corong hingga penuh, lalu penutup corong di buka dan granul dibiarkan mengalir keluar hingga kertas yang digunakan sebagai alas horizontal tertutupi oleh timbunan serbuk dengan ketinggian tertentu. Kemudian diukur puncak timbunan serbuk dan diameter lingkaran dasar timbunan. Sudut diam 
Formulasi Suspensi Kering Kombinasi Ekstrak Etanol Dan Serbuk Daging Buah Pisang Kepok Dengan Variasi Bahan Pensuspensi

antara $20^{\circ}-40^{\circ}$ menunjukkan sifat alir yang bagus. Sudut diam dihitung dengan rumus sebagai berikut :

$$
\operatorname{Tg} \Phi=\frac{2 h}{D}
$$

Dimana

$\mathrm{h}=$ tinggi timbangan serbuk $(\mathrm{cm})$

$\mathrm{D}=$ Diameter timbunan serbuk (cm)

$\Phi$ = Sudut diam $\left({ }^{0}\right)$

Sedangkan penentuan waktu alir dilakukan dengan cara ditimbang setiap formula serbuk sebanyak30 gram lalu dimasukkan kedalam corong yang lubang bawahnya ditutup dan pada bagian bawah corong diberi alas kertas. Setelah granul terisi dengan baik dan rata, tutup corongdibuka hingga granul mulai meluncur. Waktu yang dibutuhkan oleh serbuk keluar dari corong dicatat. Untuk serbuk atau granul, waktu alirnya bagus bila mempunyai waktu alir tidak lebih dari 10 detik.

\section{Penentuan Bobot Jenis dan Porositas}

Penetapan bobot jenis nyata dilakukan dengan menimbang granul sebanyak 10 gram. Kemudian dimasukkan kedalam gelas ukur $15 \mathrm{ml}$ dan dicatat volumenya (Vo).

$$
\text { Bj nyata }=\frac{\text { Bobot granul }}{\text { Volumen nyata }}
$$

Penetapan bobot jenis mampat dilakukan dengan pengetukan sebanyak 100 ketukan, lalu dicatat volumenya dan dilakukan perhitungan sebagai berikut :

Bj mampat $=\frac{\text { Bobot granul }}{\text { Volumen mampat }}$

Penetapan bobot jenis sejati dilakukan dengan cara menimbang piknometer $25 \mathrm{ml}$ yang kosong (a). Kemudian piknometer tersebut diisi dengan paraffin cair dan ditimbang kembali (b), setelah itu dimasukan granul sebanyak kuranglebih $2 / 3$ bagian piknometer dan ditimbang (c). Kemudian paraffin cair ditambahkan hingga penuh dan ditimbang kembali (d). Bobot jenis paraffin cair dapat dihitung sebagai berikut :

Bobot jenis paraffin cair $=\frac{b-a l}{25} \mathrm{~g} / \mathrm{ml}$

Bj sejati $=\frac{\text { Bobot granul }}{V p-(j / i)}$

Penentuan porositas dilakukan dengan membagi BJ mampat dengan BJ sejati dan dikali dengan $100 \%$. Hasil dari penentuan porositas menyatakan banyaknya pori-pori yang ada dalam serbuk suspensi.

$$
\text { Porositas }=\left(\frac{1-\text { Bj mamapat }}{\text { Bj sejati }}\right) \times 100
$$

\section{Pengukuran Viskositas dan Tipe}

\section{Aliran}

Pengukuran viskositas suspensi kering dilakukan setelah direkonstitusi dengan menggunakan alat viskometer 
Formulasi Suspensi Kering Kombinasi Ekstrak Etanol Dan Serbuk Daging Buah Pisang Kepok Dengan Variasi Bahan Pensuspensi

brookfield pada kecepatan 50 RPM.

Dilakukan minimal 3 kali replikasi.

Sedangkan penentuan tipe aliran dilakukan dengan cara mengukur viskositas suspensi kering yang telah direkonstitusi menggunakan viskometer brookfield pada kecepatan 2, 5, 10, 20, 30, 50 dan 100 RPM. Kemudian dihitung tekanan gesernya. Dan dibuat rheogram (kurva aliran) yang merupakan hubungan antara tekanan geser dengan kecepatan geser, untuk mengetahui tipe aliran yang terbentuk.

\section{Pengamatan Partikel Tersuspensi}

Pengujian ini dilakukan dengan menggunakan mikroskop biasa untuk melihat ukuran partikel tersuspensi. Caranya yaitu suspensi (yang sebelumnya diencerkan atau tidak) diteteskan pada slide (semacam objek dan deckglass), kemudian besarnya akomodasi mikroskop diatur pada pembesaran 40x sehingga partikel terlihat dengan jelas.

\section{Penetuan pH Sediaan}

Evaluasi $\mathrm{pH}$ sediaan menggunakan $\mathrm{pH}$ meter. Sediaan suspensi kering yang telah direkonstitusi dimasukan kedalam erlenmeyer. Celupkan $\mathrm{pH}$ meter yang sebelumnya telah dikalibrasi kedalam sediaan suspensi. Biarkan beberapa menit hingga $\mathrm{pH}$ meter terendam secara sempurna. Amati dan catat $\mathrm{pH}$ nya.

\section{Penentuan Volume Sedimentasi}

Untuk mengevaluasi volume sedimentasi digunakan gelas ukur 50 $\mathrm{ml}$. Cara pelaksanaanya yaitu sampel suspensi kering yang telah direkonstitusi dikocok sampai homogen. Dimasukan kedalam gelas ukur sampai batas tanda. Diamati tinggi sedimentasi yang terbentuk. Evaluasi ini dilakukan selama 1 bulan.

\section{HASIL PEMBAHASAN}

\section{Pemeriksaan kadar air}

Tabel 1. Hasil Perhitungan Kadar Air Dari Formulasi Suspensi Kering Kombinasi Ekstrak Etanol Kunyit (Curcuma longa L.) Dan Serbuk Daging Buah Pisang Kepok (Musa balbisiana Colla.) Dengan Variasi Bahan Pensuspensi.

\begin{tabular}{cccc}
\hline \multirow{2}{*}{ Replikasi } & \multicolumn{3}{c}{ Kadar Air (\%) } \\
\cline { 2 - 4 } & Formula A & Formula B & Formula C \\
\hline 1 & 3.488 & 1.977 & 1.596 \\
2 & 1.036 & 1.710 & 1.541 \\
3 & 1.000 & 1.242 & 1.594 \\
\hline Rata-rata & $\mathbf{1 . 8 4 2}$ & $\mathbf{1 . 6 4 3}$ & $\mathbf{1 . 5 7 7}$ \\
\hline
\end{tabular}


Formulasi Suspensi Kering Kombinasi Ekstrak Etanol Dan Serbuk Daging Buah Pisang Kepok Dengan Variasi Bahan Pensuspensi

\section{Penentuan Sudut Baring dan waktu alir}

Tabel 2. Hasil Perhitungan Sudut Baring Dari Formulasi Suspensi Kering Kombinasi Ekstrak Etanol Kunyit (Curcuma longa L.) Dan Serbuk Daging Buah Pisang Kepok (Musa balbisiana Colla.) Dengan Variasi Bahan Pensuspensi

\begin{tabular}{cccc}
\hline \multirow{2}{*}{ Replikasi } & \multicolumn{3}{c}{ Sudut Baring (Ф) } \\
\cline { 2 - 4 } & Formula A & Formula B & Formula C \\
\hline 1 & 28 & 20.3 & 18.3 \\
2 & 19 & 18.8 & 22.8 \\
3 & 21.8 & 19.3 & 18.7 \\
\hline Rata-rata & $\mathbf{2 2 . 9 3 3 3}$ & $\mathbf{1 9 . 4 6 6 6 6 7}$ & $\mathbf{1 9 . 9 3 3 3 3}$ \\
\hline
\end{tabular}

Tabel 3. Hasil Perhitungan Waktu Alir Dari Formulasi Suspensi Kering Kombinasi Ekstrak Etanol Kunyit (Curcuma longa L.) Dan Serbuk Daging Buah Pisang Kepok (Musa balbisiana Colla.) Dengan Variasi Bahan Pensuspensi

\begin{tabular}{cccc}
\hline \multirow{2}{*}{ Replikasi } & \multicolumn{3}{c}{ Waktu alir (detik) } \\
\cline { 2 - 4 } & Formula A & Formula B & Formula C \\
\hline 1 & 20.66 & 14.08 & 28.29 \\
2 & 29.25 & 27.78 & 24.55 \\
3 & 27.58 & 20.07 & 30.06 \\
\hline Rata-rata & $\mathbf{2 5 . 8 3}$ & $\mathbf{2 0 . 6 4 3 3 3}$ & $\mathbf{2 7 . 6 3 3 3 3}$ \\
\hline
\end{tabular}

\section{Penentuan Bobot Jenis dan Porositas}

Tabel 4. Hasil Perhitungan Bobot Jenis Dan Porositas Dari Formulasi Suspensi Kering Kombinasi Ekstrak Etanol Kunyit (Curcuma longa L.) Dan Serbuk Daging Buah Pisang Kepok (Musa balbisiana Colla.) Dengan Variasi Bahan Pensuspensi

\begin{tabular}{ccccc}
\hline Formula & Replikasi & BJ mampat $\mathbf{( g / m L )}$ & BJ sejati $(\mathbf{g} / \mathbf{m L})$ & Porositas $(\boldsymbol{\epsilon}) \mathbf{( \% )}$ \\
\hline \multirow{2}{*}{ A } & 1 & 0.894 & 1.063 & 15.966 \\
& 2 & 0.747 & 0.908 & 17.736 \\
& 3 & 0.751 & 0.809 & 7.146 \\
\hline \multirow{2}{*}{ B } & 1 & 0.838 & 1.096 & 23.503 \\
& 2 & 0.836 & 1.288 & 35.111 \\
& 3 & 0.837 & 1.141 & 26.577 \\
\hline \multirow{2}{*}{ C } & 1 & 0.841 & 1.065 & 21.048 \\
& 2 & 0.836 & 1.043 & 19.852 \\
& 3 & 0.838 & 0.953 & 12.037 \\
\hline
\end{tabular}


Formulasi Suspensi Kering Kombinasi Ekstrak Etanol Dan Serbuk Daging Buah Pisang Kepok Dengan Variasi Bahan Pensuspensi

\section{Pengujian Organoleptis}

Tabel 5. Hasil Pengujian Organoleptis Formulasi Suspensi Kering Kombinasi Ekstrak Etanol Kunyit (Curcuma longa L.) Dan Serbuk Daging Buah Pisang Kepok (Musa balbisiana Colla.) Dengan Variasi Bahan Pensuspensi

\begin{tabular}{|c|c|c|c|}
\hline \multirow{2}{*}{$\begin{array}{l}\text { Jenis Bahan } \\
\text { Pensuspensi }\end{array}$} & \multirow{2}{*}{$\begin{array}{c}\text { Jenis } \\
\text { Pemeriksaan }\end{array}$} & \multicolumn{2}{|c|}{ Kondisi } \\
\hline & & Sebelum & Sesudah \\
\hline \multirow[b]{2}{*}{ Formula A } & Bau & Khas aromatis & Khas aromatis \\
\hline & $\begin{array}{l}\text { Warna } \\
\text { Konsistensi }\end{array}$ & $\begin{array}{l}\text { Jingga kekuningan } \\
\text { Agak Kental }\end{array}$ & $\begin{array}{l}\text { Jingga kekuningan } \\
\text { Agak Kental }\end{array}$ \\
\hline \multirow[b]{2}{*}{ Formula B } & $\mathrm{Bau}$ & Khas aromatis & Khas aromatis \\
\hline & $\begin{array}{l}\text { Warna } \\
\text { Konsistensi }\end{array}$ & $\begin{array}{l}\text { Kuning Kecoklatan } \\
\text { Agak Kental }\end{array}$ & $\begin{array}{l}\text { Kuning Kecoklatan } \\
\text { Agak Kental }\end{array}$ \\
\hline \multirow{3}{*}{ Formula C } & Bau & Khas aromatis & Khas aromatis \\
\hline & Warna & Coklat Muda & Coklat Muda \\
\hline & Ko & Agak Kental & Agak Kental \\
\hline
\end{tabular}

\section{Penentuan Viskositas dan Tipe Aliran}

Tabel 6. Hasil Pengukuran Viskositas Formulasi Suspensi Kering Kombinasi Ekstrak Etanol Kunyit (Curcuma longa L.) Dan Serbuk Daging Buah Pisang Kepok (Musa balbisiana Colla.) Dengan Variasi Bahan Pensuspensi dengan menggunakan Viskometer Brookfield pada kecepatan 50 RPM.

\begin{tabular}{|c|c|c|c|c|}
\hline \multirow{2}{*}{ Kondisi } & \multirow{2}{*}{ Rep. } & \multicolumn{3}{|c|}{ Viskositas } \\
\hline & & Formula A & Formula B & Formula C \\
\hline \multirow{3}{*}{ Sebelum } & 1 & 3.430 & 1.560 & 6.790 \\
\hline & 2 & 3.430 & 1.540 & 6.820 \\
\hline & 3 & 3.460 & 1.510 & 6.790 \\
\hline \multicolumn{2}{|c|}{ Rata-rata } & 3.440 & 1.537 & 6.800 \\
\hline \multirow{3}{*}{ Sesudah } & 1 & 1.940 & 1.540 & 13.920 \\
\hline & 2 & 1.970 & 1.510 & 13.870 \\
\hline & 3 & 1.940 & 1.540 & 13.900 \\
\hline \multicolumn{2}{|c|}{ Rata-rata } & 1.950 & 1.530 & 13.897 \\
\hline
\end{tabular}

Tabel 7. Nilai Yield Formulasi Suspensi Kering Kombinasi Ekstrak Etanol Kunyit (Curcuma longa L.) Dan Serbuk Daging Buah Pisang Kepok (Musa balbisiana Colla.) Dengan Variasi Bahan Pensuspensi

\begin{tabular}{|c|c|c|c|c|}
\hline \multirow{2}{*}{ Kondisi } & \multirow{2}{*}{ Rep. } & \multicolumn{3}{|c|}{ Nilai Yield (dyne $\mathrm{cm}^{-2}$ ) } \\
\hline & & Formula $\mathbf{A}$ & Formula B & Formula C \\
\hline \multirow{3}{*}{ Sebelum } & 1 & 1.033 & 1.205 & 2.653 \\
\hline & 2 & 1.002 & 1.247 & 2.612 \\
\hline & 3 & 0.959 & 1.096 & 2.664 \\
\hline \multicolumn{2}{|c|}{ Rata-rata } & 0.998 & 1.183 & 2.643 \\
\hline \multirow{3}{*}{ Sesudah } & 1 & 0.594 & 0.902 & 5.974 \\
\hline & 2 & 0.587 & 1.094 & 5.907 \\
\hline & 3 & 0.537 & 1.046 & 5.911 \\
\hline
\end{tabular}


Formulasi Suspensi Kering Kombinasi Ekstrak Etanol Dan Serbuk Daging Buah Pisang Kepok Dengan Variasi Bahan Pensuspensi

\begin{tabular}{cccc}
\hline Rata-rata & 0.573 & 1.014 & 5.931 \\
\hline Penentuan pH sediaan & & \\
Tabel 8 . Hasil Pengukuran pH Formulasi Suspensi Kering Kombinasi Ekstrak Etanol \\
Kunyit (Curcuma longa L.) Dan Serbuk Daging Buah Pisang Kepok (Musa \\
balbisiana Colla.) Dengan Variasi Bahan Pensuspensi
\end{tabular}

\begin{tabular}{ccccc}
\hline \multirow{2}{*}{ Kondisi } & \multirow{2}{*}{ Rep. } & \multicolumn{3}{c}{ pH } \\
\cline { 3 - 5 } & 1 & Formula A & Formula B & Formula C \\
\hline \multirow{2}{*}{ Sebelum } & 2 & 6,16 & 6,87 & 7,26 \\
& 3 & 6,14 & 6,97 & 7,28 \\
& 1 & 5,73 & 6,99 & 7,30 \\
\hline \multirow{2}{*}{ Sesudah } & 2 & 5,63 & 6,37 & 6,66 \\
& 3 & 5,65 & 6,43 & 6,68 \\
& 3 & 6,45 & 6,65 \\
\hline
\end{tabular}

\section{Pengukuran volume sedimentasi}

Tabel 9. Hasil Pengukuran Volume Sedimentasi dari Formulasi Suspensi Kering Kombinasi Ekstrak Etanol Kunyit (Curcuma longa L.) Dan Serbuk Daging Buah Pisang Kepok (Musa balbisiana Colla.) Dengan Variasi Bahan Pensuspensi

\begin{tabular}{cccc}
\hline Formula & Volume Endapan $(\mathbf{m L})$ & Volume Suspensi Total $(\mathbf{m L})$ & Volume Sedimentasi \\
\hline A & 73 & 100 & 0.73 \\
B & 70 & 100 & 0.7 \\
C & 98 & 100 & 0.98 \\
\hline
\end{tabular}

Keterangan:

$\mathrm{A}=$ Formulasi suspensi kering dengan bahan pensuspensi gum xanthan konsentrasi $0,5 \%$

$\mathrm{B}=$ Formulasi suspensi kering dengan bahan pensuspensi magnesium aluminium silikat konsentrasi $4 \%$

$\mathrm{C}=$ Formulasi suspensi kering dengan bahan pensuspensi kombinasi gum xanthan : magnesium aluminium silikat konsentrasi $(0,5 \%$ : $1 \%)$

\section{PEMBAHASAN}

Kunyit atau Curcuma longa L. biasanya telah digunakan sebagai pengobatan tradisional untuk berbagai gejala seperti inflamasi, gastritis dan tukak lambung. Hasil penelitian menunjukan dengan kunyit laju penyembuhan meningkat $23,3 \%$ pada kelinci dan $24,4 \%$ pada tikus. Usaha identifikasi kunyit mengarah kepada penemuan kurkumin. Kurkumin meningkatkan mucus lambung sehingga aktivitas nyeri lambung dapat dijelaskan melalui stimulus produksi mucus. Selain kunyit, pisang dari keluarga Musaceae secara empiris juga digunakan sebagai obat sakit maag. Kandungan kimia dari buah pisang yang dapat mengobati penyakit adalah sitoindosin, tannin dan amilum.

Kebanyakan pasien yang terkena ulkus menginginkan suatu sediaan dengan efek yang cepat. Berdasarkan hal ini maka sediaan 
Formulasi Suspensi Kering Kombinasi Ekstrak Etanol Dan Serbuk Daging Buah Pisang Kepok Dengan Variasi Bahan Pensuspensi

yang dapat menghasilkan efek yang cepat adalah suspensi. Karena ukuran partikel dari zat tersuspensi sangat kecil sehingga tidak membutuhkan waktu untuk terdegradasi maupun teragreagsi. Namun, karena kandungan amilum dari pisang yang baik untuk pertumbuhan mikroorganisme ketika terhidrasi maka salah satu cara untuk menghindari hal tersebut salah satunya adalah dibuat dalam bentuk suspensi kering.

Penelitian ini diawali dengan menentukan bahan pensuspensi (optimasi) yang aman untuk digunakan secara oral dan menentukan konsentrasi dari bahan pensuspensi tersebut yang dapat menghasilkan suspensi kering dengan kekentalan yang baik ketika direkonstitusi, sehingga dapat mempertahankan keseragaman dispersi partikel, memperlambat proses sedimentasi dan menghambat pembentukan lempeng keras (Hard cake) pada dasar botol yang susah terdispersi kembali setelah dikocok.

Selain aman, pemilihan bahan pensuspensi juga didasarkan pada tipe aliran yang ideal untuk suspensi. Berdasarkan literatur, Idealnya suspensi seharusnya memperlihatkan sifat aliran tiksotropi, dimana suspensi seharusnya mengental ketika didiamkan tetapi encer ketika dikocok. Bahan pensuspensi yang dapat menghasilkan aliran tiksotropi diantaranya adalah guar gum, gum xantan dan turunan clay. Setelah diperoleh formula suspensi kering yang baik, maka selanjutnya dilakukan pengujian kestabilan suspensi. Pengujian ini dilakukan dalam dua tahap yaitu pengujian untuk suspensi kering dan pengujian yang dilakukan ketika suspensi kering direkonstitusi.

Pengujian pada suspensi kering meliputi :

\section{Pengujian kadar air}

Pengujian kadar air bertujuan untuk melihat kandungan air yang terdapat dalam serbuk suspensi. Hasil penelitian diperoleh bahwa semua formula memenuhi persyaratan uji kadar air, yaitu diatas $0 \%$ sampai sedikit dibawah $100 \%$.

Penentuan sudut baring dan waktu alir

\section{Penentuan sudut baring}

Penentuan sudut baring bertujuan untuk memberikan nilai kualitatif dari gaya kohesi internal dan efek hambatan yang mungkin dipakai pada pencampuran serbuk, pencetakan tablet atau pemasukan kedalam cangkang atau wadah. Dari penelitian, menunjukan bahwa hanya formula A (Formula suspensi kering 
Formulasi Suspensi Kering Kombinasi Ekstrak Etanol Dan Serbuk Daging Buah Pisang Kepok Dengan Variasi Bahan Pensuspensi

dengan bahan pensuspensi gum xanthan konsentrasi $0,5 \%$ yang memenuhi standar uji sudut baring, yaitu $22,93^{\circ}$. Berdasarkan analisis statistik dengan menggunakan rancangan acak lengkap (RAL) diperoleh hasil bahwa tidak ada perbedaan sudut baring antara ketiga formula.

\section{Penentuan waktu alir}

Secara alternatif, ketahanan terhadap gerakan partikel dapat mempengaruhi waktu alir dari partikel tersebut. Semakin kuat ketahanan partikel maka semakin lama waktu alirnya. Dari penelitian menunjukan hasil bahwaketiga formula tidak memenuhi syarat uji waktu alir. Berdasarkan analisis statistik menggunakan rancangan acak lengkap (RAL) diperoleh hasil bahwa ketiga formula suspensi kering tidak memperlihatkan adanya perbedaan pada waktu alir suspensi tersebut.

\section{Penentuan bobot jenis dan porositas}

Pengukuran berat jenis mampat dan sejatibertujuan untuk memberikan informasi tentang jumlah udara yang masuk selama pembuatan suatu sediaan. Selain itu pengukuran ini jugamembantu dalam menentukan jumlah pori-pori yang ada dalam partikel suspensi. Porositas teoritis dari suatu serbuk yang terdiri dari bola-bola yang sama dalam pengepakan paling dekat adalah $26 \%$ dan untuk pengepakan yang paling longgar adalah $48 \%$. Berdasarkan penelitian, diperoleh hanya formula $B$ yang memenuhi persyaratan porositas yaitu berada diantara 26\%-48\%. Sesuai dengan analisis statistik dengan menggunakan rancangan acak lengkap (RAL) diperoleh hasil bahwa terlihat adanya perbedaan porositas antar formula.

\section{Pengujian Stabilitas Suspensi Kering yang telah direkonstitusi}

Pengujian stabilitas suspensi dilakukan setelah direkonstitusi dengan menggunakan aquadest. Pengujian suspensi basah dilakukan dengan penyimpanan dipercepat dengan menggunakan metode Freezethaw, dimana suspeni basah tersebut disimpan pada dua suhu ekstrim, yaitu pada suhu $5^{\circ} \mathrm{C}$ yang dimasukan dalam lemari pendingindan $35^{\circ} \mathrm{C}$ dalam lemari pemanas secara bergantian masing-masing 12 jam selama 10 kali siklus.

\section{Uji Organoleptis}

\section{Pengujian} organoleptis bertujuan untuk memberikan data tentang warna, bau dan konsistensi dari keseluruhan formulasi suspensi. Pengujian organoleptis menunjukan 
Formulasi Suspensi Kering Kombinasi Ekstrak Etanol Dan Serbuk Daging Buah Pisang Kepok Dengan Variasi Bahan Pensuspensi

tidak adanya perubahan pada warna, bau dan konsistensi dari ketiga formula selama kondisi dipaksakan.

\section{Uji homogenitas}

Tujuan dari pengujian homogenitas adalah memberikan data tentang keseragaman distribusi partikel suspensi. Berdasarkan pengujian homogenitas diperoleh hasil bahwa ketiga formula suspensi tersebut homogen.

\section{Penentuan viskositas dan tipe aliran} Penentuan viskositas

Sesuai dengan analisis statistik dengan menggunakan rancangan acak kelompok (RAK) diperoleh hasil bahwa terlihat adanya perbedaan viskositas yang sangat signifikan diantara ketiga formula suspensi kering.

\section{Penentuan Tipe Aliran}

Penentuan tipe aliran dilakukan dengan melihat reogram (kurva alir) yang terbentuk. Dilihat dari reogram, maka aliran yang ada pada formula $A$ dan C memperlihatkan aliran non newton yang tidak dipengaruhi oleh waktu, dan formula B memperlihatkan aliran non newton yang dipengaruhi oleh waktu. Selain reogram, penentuan tipe aliran juga dapat dilihat dari ada atau tidak adanya nilai yield. Dari penelitian, diperoleh bahwa ketiga formula suspensi kering tersebut mempunyai nilai yield dan karena mempunyai nilai yield maka ketiga formula tersebut termasuk dalam aliran plastis, tetapi karena reogram formula B tidak berimpitan maka formula $B$ (Formula suspensi kering dengan bahan pensuspensi magnesium aluminium silikat konsentrasi 4\%) memperlihatkan aliran tiksotropi plastis. Sesuai dengan analisis statistik dengan menggunakan rancangan acak kelompok (RAK) diperoleh hasil bahwa terlihat adanya perbedaan nilai yield yang sangat signifikan diantara .

\section{Penetapan pH suspensi}

Penetapan $\mathrm{pH}$ bertujuan untuk menentukan $\mathrm{pH}$ dari sediaan suspensi kering. Berdasarkan penelitian, diperoleh hasil bahwa $\mathrm{pH}$ dari ketiga formulasi suspensi kering tersebut adalah asam.

\section{Pengamatan partikel tersuspensi}

Pengujian selanjutnya adalah analisa ukuran partikel tersuspensi. Namun karena keterbatasan alat, sehingga pengukuran diameter partikel tersuspensi tidak dapat dilakukan tetapi hanya diamati. Berdasarkan hasil pengamatan dapat dikatakan bahwa selama kondisi penyimpanan dipercepat terjadi penggabungan partikel tersuspensi.

\section{Penentuan volume sedimentasi}

Volume sedimentasi bertujuan untuk memberikan informasi tentang 
Formulasi Suspensi Kering Kombinasi Ekstrak Etanol Dan Serbuk Daging Buah Pisang Kepok Dengan Variasi Bahan Pensuspensi

sistem suspensi yang terbentuk.

Volume sedimentasi adalah perbandingan dari volume akhir endapan terhadap volume awal dari suspensi sebelum mengendap. Dari hasil penelitian diperoleh bahwa volume sedimentasi dari ketiga formula suspensi kering adalah 0,$73 ; 0,7$ dan 0,98 .

\section{KESIMPULAN}

Bahan pensuspensi yang menghasilkan suspensi kering yang stabil secara farmaseutika adalah magnesium aluminium silikat dengan konsentrasi $4 \%$.

\section{DAFTAR PUSTAKA}

Chattopadhyay I., dkk., 2004. Turmeric and Curcumin: Biological Actions and Medical Application; 87 (1) : 11

Dipiro JT, Wells BG, Schwinghammer TL, Hamilton CW. 2008. Pharmacotherapy Hand Book, Seventh Editions. New York : Lange Medical Books, McGraw Hill.

Imam and Akter Saleha, 2011. Journal of Applied Pharmaceutical
Science 01, (05); $2011: 14-$ 20.

Kim DC., dkk., 2005. Curcuma longa Extract Protect Against Gastric Ulcers by Blocking $\mathrm{H}_{2}$ Histamine Receptors; 28 (12) : 184-185

Lewis.dkk. 1999. A Natural Flavanoid Present in Unripe Plantain Banana Pulp (Musa sapientum L. var. Paradisiaca) Protects the Gastricmucosa From Aspirininduced Erosions. Journal Ethopharmacol, 65 (3) : 283

Price, 2006. Patofisiologi : Konsep Klinis Proses-Proses Penyakit. Edisi 6. Jakarta : EGC

Ronita De., 2009. Antimicrobial Activity of Curcumin Against Helicobacter pylori Isolates From India and During Infections in Mice; 53 (4) : 1592-1597

Thong-Ngam., dkk., 2012. Curcumin prevents indomethacininduced gastropathy in rats; 18 (13) : 1479-1484

Yusuf, M. 2012. Khasiat Super minuman Alami Tradisional "Beras Kencur dan Kunyit Asam", Yogyakarta : Diandra Pustaka Indonesia 